\title{
Superficial Deep-Water Sediments of the Eastern Marmara Basin
}

\author{
G. Evans, ${ }^{1}$ H. Erten, ${ }^{2}$ S. N. Alavi, ${ }^{3}$ H. R. Von Gunten ${ }^{4}$ and M. Ergin ${ }^{5}$ \\ 'Department of Geology, Royal School of Mines, Imperial College, London, UK; ${ }^{2}$ Department of \\ Chemistry, Faculty of Engineering and Science, Bilkent University, Ankara, Turkey; ${ }^{3}$ Institute of \\ Marine Sciences, Middle East Technical University, Erdemli, Turkey; ${ }^{4}$ Eidg Institut fur \\ Reaktorforschung, CH-5303 Wurenlingen, Switzerland; and ${ }^{5}$ Institute of Marine Sciences, Middle East \\ Technical University, Erdemli, Turkey
}

\begin{abstract}
Superficial sediments (top - $\mathrm{Im}$ ) of the Eastern Mediterrancan Ba$\sin$, Sea of Marmara, Turkey accumulated rapidly $(0.087 \pm 0.012$ $\mathrm{g} / \mathrm{cm}^{2} \cdot \mathrm{y}$ ) by hemipelagic sedimentation with only limited amounts of gravity flow or bottom current action under low oxygenated but not anoxic conditions. They have restricted faunas, relatively higher organic carbon (1-1.8\%) and lower calcium carbonate (14-20\%) contents than other Eastern Mediterranean Basin sediments. Sedimentation shows little change over the last millenium except for an increase in $\mathrm{Cu}, \mathrm{Zn}, \mathrm{Pb}, \mathrm{Cr}$, and $\mathrm{P}$ over the last few centuries. The increase was most likely caused by increased metallurgical activities since the eightcenth century but are not at sufficient levels for the area to be regarded as polluted.
\end{abstract}

\section{Introduction}

The Sea of Marmara is an area of considerable oceanographic interest lying between the brackish Black Sea to the north and the saline Aegean Sea to the south (Fig. 1). The hydrography is dominated by the interaction of the Mediterranean waters flowing in as an undercurrent through the Dardanelles and the outflow of surface brackish waters from the Black Sea through the Bosporus (Miller 1983, Ozsoy and others 1986). This results in a stratified water column with a marked halocline separating a superficial layer of low salinity $(22-25 \%$ ) water from underlying saline $(38.5 \%$ ) water, which fill the rest of the basin. This lower water has a temperature of $14.5-15^{\circ} \mathrm{C}$. The strong stratification of the water column coupled with the topo- graphic restriction imposed by the two shallow sills of the Dardanelles and Bosporus inhibits efficient circulation of deep waters. This situation, together with the relatively high average rate of primary productivity, estimated to be $60 \mathrm{~g}:$ carbon $/ \mathrm{m}^{2} \cdot \mathrm{y}$ leads to oxygen depletion in the sub-halocline waters (Unluata and Ozsoy, 1986). The oxygen deficiency becomes more pronounced toward the east as the only source of oxygen replacement for the sub-halocline waters is the underflow through the Dardanelles. Thus, the oxygen content falls to about $0.9 \mathrm{ml} / 1 \mathrm{O}_{2}$ at approximately $1,000 \mathrm{~m}$ in the Eastern Marmara Basin. Surface waters are generally very productive in this basin (Basturk and others, 1986) mainly because of intense upward mixing (entrainment) of subsurface waters into the surface layer (photic zone) at the entrance into the Bosporus as well as a large supply of nutrients brought in the surface flow from the Black Sea.

The character of the bottom sediments is very poorly known. The only published data are those in Koreneva (1971) on the palynology of a core from the Western Marmara Basin, and in a paper by Stanley and Blanpied (1980). In 1984, an opportunity became available to collect three gravity cores of approximately $1 \mathrm{~m}$ length, using boomerang corers, in the Eastern Marmara Basin (Fig. 2) at depths of approximately $1,200 \mathrm{~m}$ and at locations very close to cores PG507-G7 and PG507-G8 (hereafter G7 and G8) of the latter authors. The opportunity to collect the cores arose quite suddenly. Originally, we hoped to take a 


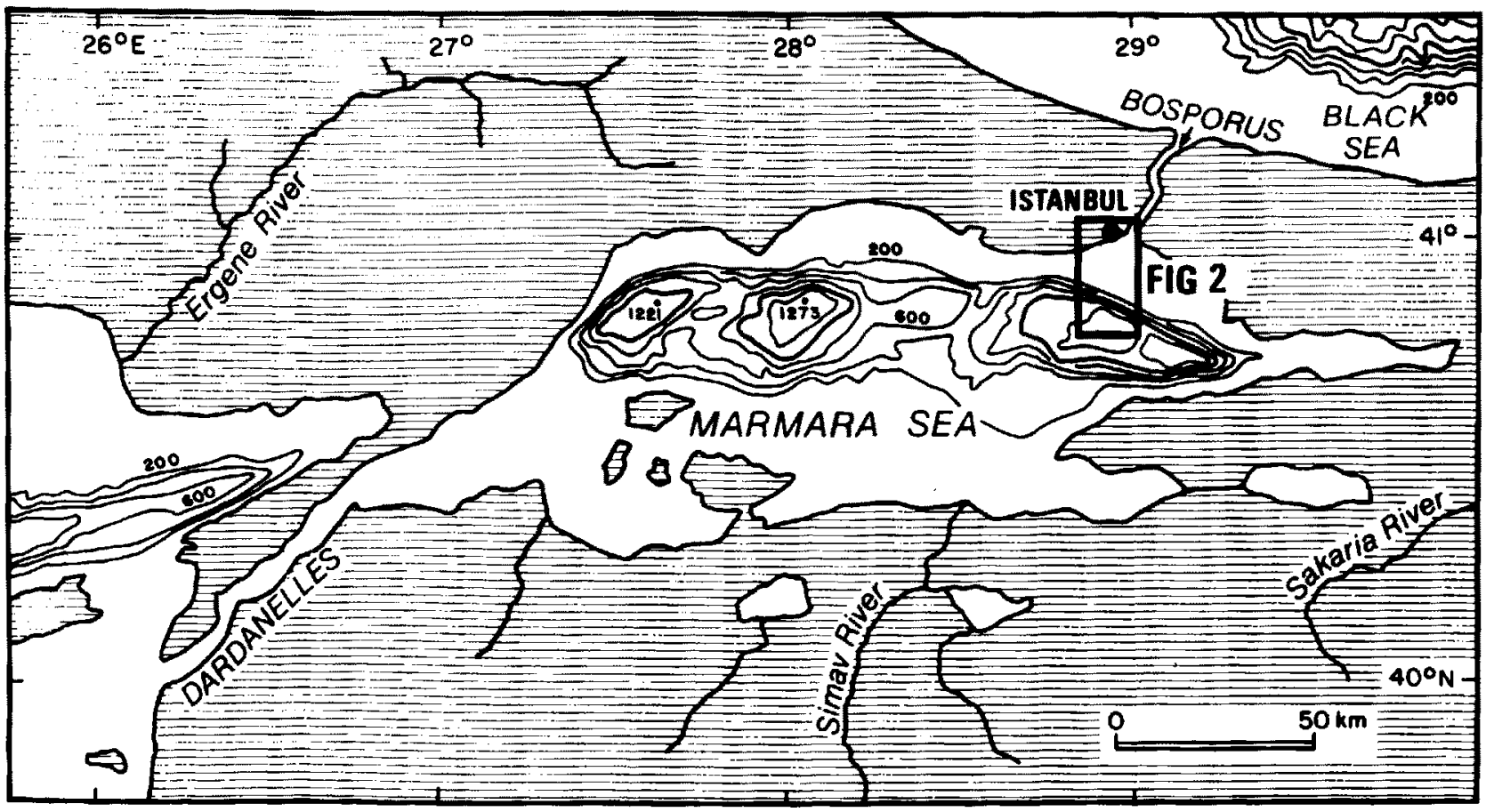

Figure 1. General bathymetry (in meters) of the Sea of Marmara and its drainage system. (Bathymetry from Intergovernmental Oceanographic Commission-United Nations Educational and Cultural Organization, 1981, International Bathymetric charts of the Mediterranean Sea, Charts 4 and 5).

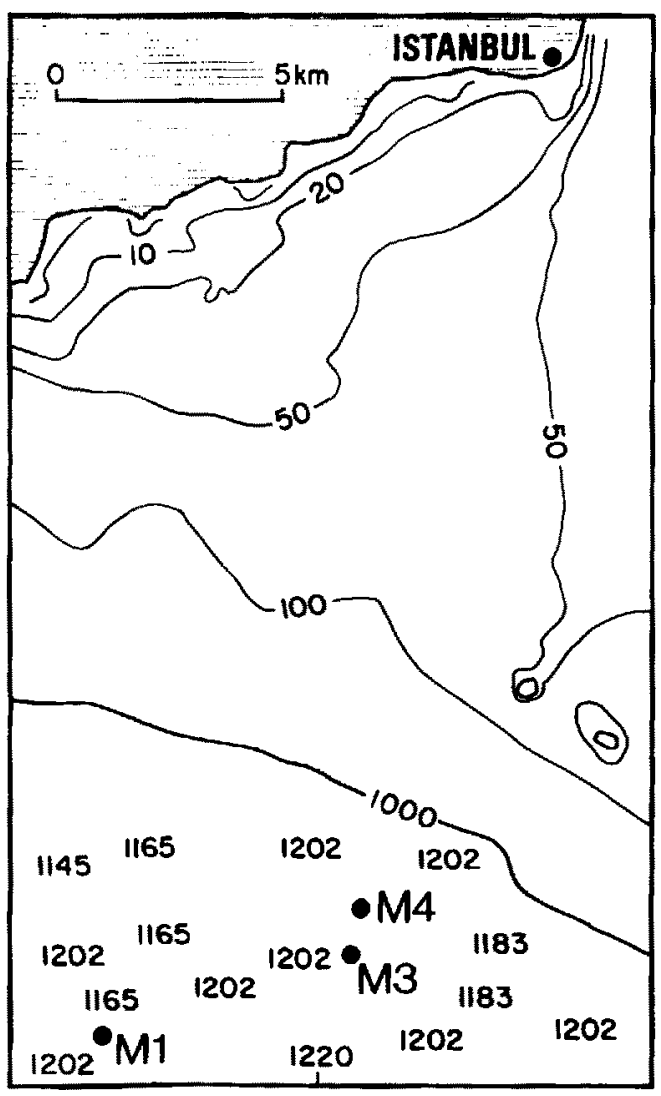

Figure 2. Coring locations. (Local bathymetry in meters from Turkish Hydrographic Office, Chart 2923, 1980). series of cores in the three Marmara basins as well as on the intervening ridges to confirm and extend the work of Stanley and Blanpied (1980). Also, as concern had been expressed by the Turkish authorities on the possible degeneration due to anthropogenic pollution of the Sea of Marmara, this needed to be checked. The research ship employed did not possess a coring winch hence the necessity for boomerang corers. Furthermore, due to the availability of the ship for only one day, the subsequent non-functioning of some of the boomerang corers and the onset of violent stormy conditions, only three cores were obtained. All of these were in the Eastern Basin.

Although only three cores were collected, and only two were available for detailed study, in view of the scarcity of data from this area and some conflicting views on the composition and nature of the surface sediments (Anastasakis 1985), it is considered useful to make the data available to other researchers concerned with this important area of two-way water exchange between the Black and Mediterranean Seas. The data supplement those of Stanley and Blanpied (1980); but while confirming the relative richness and poverty of the sediments respectively in organic-carbon and carbonates, they reveal some striking differences as to the values of these properties. The data reported here confirm that the rate of sediment accumulation on the basin floor is relatively high, as was first noted by Koreneva (1971). 


\section{Lithology and Paleontology}

The cores consist of clayey-silt with very small amounts of sand (2\%). Grain-size analyses of 12 samples from core M3 show that silt represents between approximately $64 \%$ to $88 \%$ of the sediments, and that clay ranges between $11 \%$ to $40 \%$ (Table 1). The sediments were uniformly dark colored when opened and showed no obvious divisions while still wet. The top $5.3 \mathrm{~cm}$ of $\mathrm{Ml}$ and the top $2.5 \mathrm{~cm}$ of M4 had colors 10YR 5/ 4; both had color $5 Y 5 / 2$ over the remainder of their length (G.S.A. rock color chart as well. $\mathrm{X}$-ray radiographs of cores M1 and M4 show that they are relatively uniform and consist predominantly of bioturbated sediments (Fig. 3); this bioturbation is probably mostly produced by meiofauna. There are a few thin horizons which show some cross-laminated silts and other horizons with diffuse traces of horizontal stratification (Fig. 3). At the base of core $\mathrm{Ml}$, between $85-88 \mathrm{~cm}$, a series of cross-laminated sediments overlie what appears to be an erosional surface. Beneath this surface, the sediment is less bioturbated and has a distinctly different structure to that higher in the core. It is more homogeneous without bioturbation and has a slight trace of stratification. A similar change is seen at the base of core M4 at a similar depth. However, in this case, it is at the extreme bottom of the core in the zone occupied by the core catcher and consequently only a small amount of sediment is preserved.

Generally, it appears, from the evidence of the $x$ ray radiographs, that apart from a few intervals, the greater part of the sequence represented by the cores has accumulated by hemipelagic deposition from the overlying waters with bottom currents or mass transport playing only a minor role. It is likely that the noticeable break found at the bottom of M1 and M4 is the same discontinuity recorded by Stanley and Blanpied (1980) in their cores G7, G8, and G9.

Studies of samples from the cores showed that biogenic carbonate is the main constituent of the sand fraction. Small benthic mollusks, foraminifers, and echinoid spines are the chief components with only minor amounts of siliciclastic sediments composed of quartz, feldspar, and heavy minerals. Faecal pellets are common in the upper parts of the cores but are less common at greater depths due to a smaller original production or because of obliteration by compaction. Pyrite is also a common constituent, usually found infilling foraminiferal tests. Examination of a series of selected samples under SEM showed that coccoliths of Emiliania huxleyi (J. Young, Personal Communication, 1987) are present, but always in small numbers throughout the cored sequences, becoming more frequent close to the bottoms of the cores. Diatoms are generally absent except for a few corroded relics (S. Phethean, Personal Communication 1987).

More detailed studies of benthic foraminifers (Alavi, 1988) have shown that the fauna is dominated by hyaline species, mainly Brizalina spp., Bulimina spp., Chilostomella mediterranensis, and Melonis pompilioides. The benthic foraminiferal assemblages are less diverse than typical bathyal assemblages from other Eastern Mediterranean basins, reflecting the dysaerobic conditions prevailing in the bottom waters of the basin.

Planktic foraminifers are represented by only two small species, Globigerina quinqueloba and Turborotalita clarkei. The former is an indicator of higher productivity zones in the open ocean (Be' 1977), and it is reported to be common in deep-water surface sediments from the northern part of the Aegean Sea (Thunell, 1978). The latter one is considered to be an ecophynotype of $G$ quinqueloba, which occurs in anomalously large numbers in association with some sapropels from the late Quaternary deep-sea record of the Eastern Mediterranean basins (Blanc-Vernet and others 1984). The assemblage is much restricted in comparison with those of the other Mediterranean basins (Thunell 1978), presumably due to the oligohaline surface conditions. Planktic foraminifers are totally absent in the Black Sea (Shimkus and Trimonis 1974).

Generally, benthic foraminiferal assemblages show little evidence of the transportation of tests of typically shelf-dwelling species by gravitationally induced down-slope transport of sediments, as less than $14 \%$ of the total counted ( $>63$ micron) benthic tests in each sample is of shelf origin. The latter tests mostly belong to juvenile individuals and are restricted to fine and medium sand fractions. This level of faunal mixing is found commonly in hemipelagic fan sediments at the foot of the continental slope (Brunner and Normark 1985). The evidence provided by the sedimentary structures supports this conclusion as graded intervals or gravity induced flow structures are, as already discussed, unimportant in the cores. The small amount of redeposited tests were most probably resuspended at the times of great turbulence in coastal waters and subsequently transported offshore, where they finally settled to the bottom of the basin, which is only about $15 \mathrm{~km}$ away from the coast (Fig. 1). Resuspension of shelf sediments and their delivery to the adjacent bathyal areas have been demonstrated to play an important role in the process of sediment transport on the continental margin of Washington (Carson and others 1986). This mode of transport requires the flow of permanent currents over a shelf which receives a large supply of fluviatile sediments; it becomes particularly important at the times of stormy weather or during flood conditions. As a result, a bottom nephe- 
Table 1. Grain Size Analysis of Samples from Core M3

\begin{tabular}{|c|c|c|c|c|}
\hline $\begin{array}{l}\text { Depth } \\
(\mathrm{cm})\end{array}$ & $\begin{array}{c}\text { Gravel } \% \\
(>2.00 \mathrm{~mm})\end{array}$ & $\begin{array}{c}\text { Sand } \% \\
(0.063-2.00 \mathrm{~mm}) \\
\end{array}$ & $\begin{array}{c}\text { Silt \% } \\
(0.039-0.063 \mathrm{~mm})\end{array}$ & $\begin{array}{c}\text { Clay } \% \\
(<0.039 \mathrm{~mm})\end{array}$ \\
\hline $0-2$ & 0 & 2.08 & 66.75 & 31.17 \\
\hline $2-4$ & 0 & 1.86 & 71.69 & 26.45 \\
\hline $4-6$ & 0 & 0.81 & 69.34 & 29.85 \\
\hline $6-8.5$ & 0 & 1.38 & 72.67 & 25.95 \\
\hline $8.5-10$ & 0 & 1.71 & 73.77 & 24.52 \\
\hline $15-17$ & 0 & 2.55 & 64.11 & 33.34 \\
\hline $25-27$ & 0 & 2.71 & 57.3 & 39.98 \\
\hline $35-37$ & 0 & 4.76 & 58.51 & 36.73 \\
\hline $45-47$ & 0 & 0.76 & 87.69 & 11.55 \\
\hline $55-57$ & 0 & 1.07 & 81.31 & 17.62 \\
\hline $65-67$ & 0 & 1.84 & 86.67 & 11.49 \\
\hline $75-77$ & 0 & 0.77 & 60.12 & 39.11 \\
\hline
\end{tabular}

loid layer develops over the shelf which may protrude horizontally into offshore waters as a detached turbid layer, or move down the slope as a dilute turbid water current. The southern shelf of the Sea of Marmara receives the bulk of the rivers sediment supplied to this basin (Fig. 1) (Ozsoy and others 1986). The annual average suspended load of all the rivers, based on several years measurements, amounts to about 60 $\mathrm{mg} / 1$ (D.S.I. 1985, 1987). Therefore, it is quite likely that much of the silt and clay fractions of the sediments, along with a small amount of fine sand, is transported to the basin floor as resuspended shelf materials from the southern shelf.

As with the sedimentary structures, these micropalaeontological observations show that there is little evidence of pronounced environmental variations throughout the cores except for near the base of the cored sequence. Below $88 \mathrm{~cm}$ in core $\mathrm{M} 1$ there is a noticable increase in the abundance of Bulimina inflata which increases to about $45 \%$ of the benthic tests (Alvai, 1988). Together with a decrease in the relative abundances of $C$. Mediterranensis, $M$. pompilioides, and Globobulimina pseudospinescens toward the bottom of the cores, this event appears to indicate that the cores have just penetrated a horizon which was deposited under better oxygenated conditions than existed during the deposition of the upper part of the cored sequence. The latter taxa are reported to be more tolerant of low oxygen conditions in recent deep-sea sediments (Corliss 1985). They also occur more abundantly in or close to some late Quaternary sapropels from the eastern Mediterranean basins (Mullineaux and Lohmann 1981, Nolet and Corliss 1987).

\section{Geochemistry}

The sediments are relatively enriched (based on 46 analyses) in organic-carbon $1 \%-1.8 \%$ (analyzed us- ing the Perkins-Elmer dry-combustion method) or 1\%$1.3 \%$ (based on 12 analyses using a chromic acid titration method) when compared to normal basinal sediments with average values of approximately $0.5 \%$. However, they are not as rich as some of the Quaternary deep-water sapropels described from the Eastern Mediterranean (Anastasakis and Stanley 1984). If the definition of Kidd and others (1978) is accepted, the sediments described here should be regarded as sapropelic sediments. The values obtained using two techniques (the Perkin-Elmer dry-combustion and the chromic acid titration) are markedly lower-by a factor of 4 to 5 -than those reported by Stanley and Blanpied (1980).

The total carbonate content of the sediments of the cores (expressed as $\mathrm{CaCO}_{3}$ ) varies from $14 \%-20 \%$ (based on 46 analyses, Table 2). The sediments are thus generally richer in siliciclastic materials than most other Eastern Mediterranean basinal sediments, and this is the main reason for the observed high rate of sedimentation (see below). This is not surprising as the Eastern Marmara Basin is land-locked and is relatively closer to terrigenous sources of sediment when compared to other Mediterranean basins. Again these values of carbonate are noticeably different from those reported by Stanley and Blanpied (1980), who gave values of only up to approximately $6 \%$. Neither the organic carbon nor the $\mathrm{CaCO}_{3}$ show any clear trend with depth (Table 2), and, as with other faunal and sedimentary structural properties, indicate little change in conditions throughout the deposition of the cored sequence.

Analyses of various elements (e.g. Fe, Al, Ti, Mo, $\mathrm{V}, \mathrm{Co}, \mathrm{Cr}, \mathrm{Pb}, \mathrm{Ni}, \mathrm{Zn}, \mathrm{P}$, and $\mathrm{Cu}$ ) of successive 2 $\mathrm{cm}$ increments throughout cores $\mathrm{Ml}$ and $\mathrm{M} 4$ were made using Inductively Coupled Plasma Atomic Emission Spectrometry (ICP/AES). A detailed list of chemical analyses of $2 \mathrm{~cm}$ intervals down cores MI and M4 

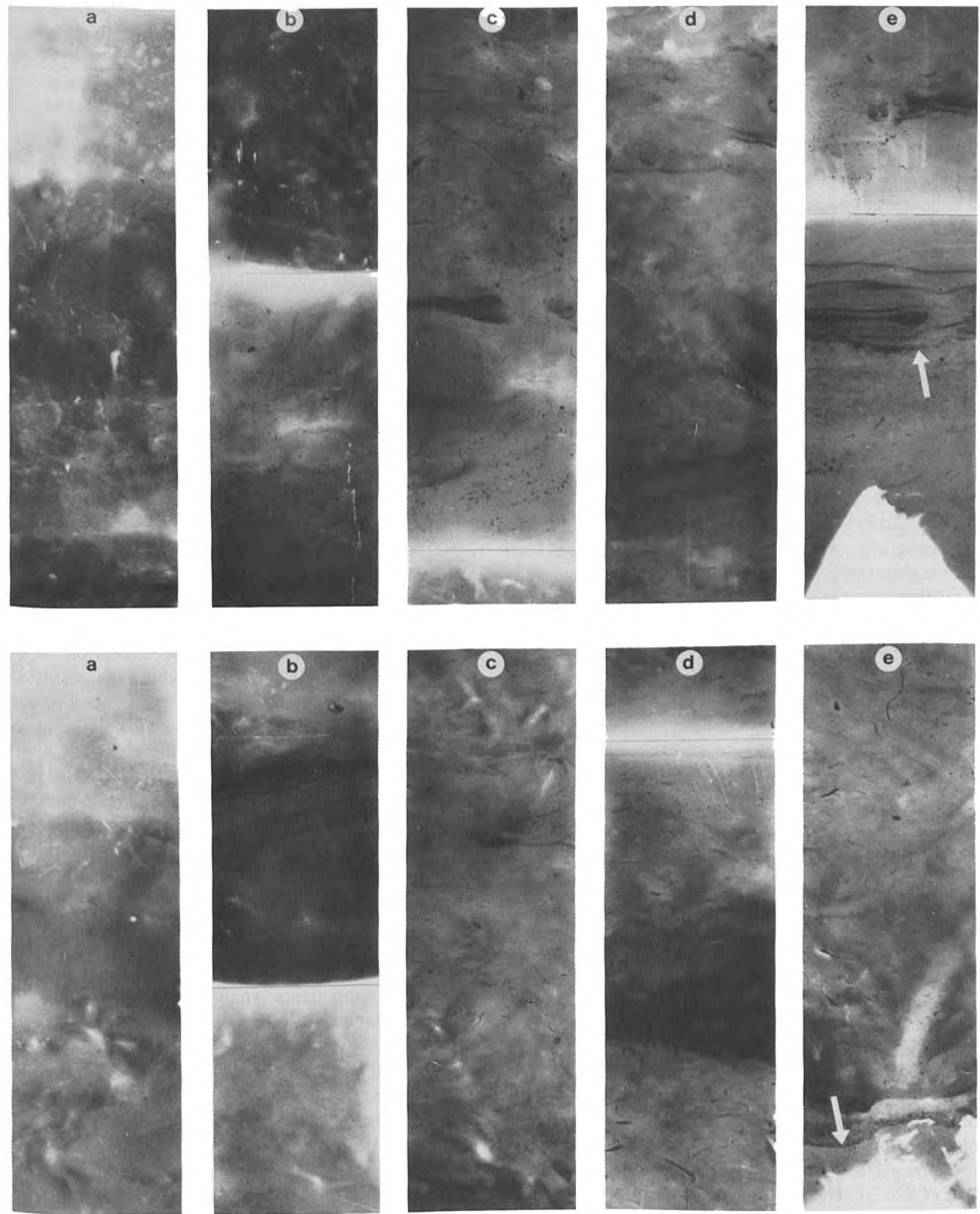

Figure 3. X-ray radiographs of cores M1 and M4 (upper and lower, respectively): M1: (a) 0-19 cm; (b) $19-38 \mathrm{~cm}$; (c) $38-57 \mathrm{~cm}$; (d) $57-76 \mathrm{~cm}$ (e) $76-96 \mathrm{~cm}$; M4: (a) 0-18 cm; (b) $18-36 \mathrm{~cm}$; (c) $36-54 \mathrm{~cm}$; (d) $54-72 \mathrm{~cm}$ (e) $72-88 \mathrm{~cm}$. The marked break referred to in the text is shown by a white arrow at the base of each core. 
Table 2. Organic Carbon and Calcium Carbonate Contents of the Sediments from Cores MI and M4. Carbonate has been expressed as if it is all in the form of Calcium Carbonatc: (a) Ml; (b) M4

\begin{tabular}{|c|c|c|c|}
\hline & Depth & $\begin{array}{l}\text { Organic } \\
\text { Carbon } \%\end{array}$ & $\begin{array}{c}\text { Calcium } \\
\text { Carbonate } \%\end{array}$ \\
\hline \multirow[t]{24}{*}{ (a) } & $0-2$ & 1.82 & 15.25 \\
\hline & $4-6$ & 1.41 & 16.58 \\
\hline & $8-10$ & 1.30 & 15.42 \\
\hline & $12-14$ & 1.28 & 18.58 \\
\hline & $16-18$ & 1.33 & 15.00 \\
\hline & $20-22$ & 1.36 & 19.25 \\
\hline & $24-26$ & 1.82 & 14.75 \\
\hline & $28-30$ & 1.74 & 18.67 \\
\hline & $32-34$ & 1.64 & 17.50 \\
\hline & $36-38$ & 1.47 & 17.58 \\
\hline & $40-42$ & 1.44 & 15.25 \\
\hline & $44-46$ & 1.72 & 16.08 \\
\hline & $48-50$ & 1.56 & 16.08 \\
\hline & $52-54$ & 1.21 & 20.50 \\
\hline & $56-58$ & 1.38 & 17.17 \\
\hline & $60-62$ & 1.15 & 16.50 \\
\hline & $64-66$ & 1.30 & 19.08 \\
\hline & $68-70$ & 1.24 & 18.67 \\
\hline & $72-74$ & 1.57 & 15.75 \\
\hline & $76-78$ & 1.44 & 20.17 \\
\hline & $80-82$ & 1.26 & 17.17 \\
\hline & $84-86$ & 1.43 & 18.58 \\
\hline & $88-90$ & 1.47 & 17.67 \\
\hline & $92-94$ & 1.28 & 17.50 \\
\hline \multirow[t]{22}{*}{ (b) } & $0-2$ & 1.83 & 17.92 \\
\hline & $4-6$ & 1.43 & 17.08 \\
\hline & $8-10$ & 1.31 & 15.50 \\
\hline & $12-14$ & 1.21 & 16.00 \\
\hline & $16-18$ & 1.45 & 15.50 \\
\hline & $20-22$ & 1.28 & 16.92 \\
\hline & $24-26$ & 1.26 & 17.25 \\
\hline & $28-30$ & 1.28 & 16.33 \\
\hline & $32-34$ & 1.51 & 18.33 \\
\hline & $36-38$ & 1.25 & 17.83 \\
\hline & $40-42$ & 1.14 & 18.17 \\
\hline & $44-46$ & 1.09 & 17.58 \\
\hline & $48-50$ & 1.18 & 19.08 \\
\hline & $52-54$ & 1.22 & 16.08 \\
\hline & $56-58$ & 1.11 & 17.08 \\
\hline & $60-62$ & 1.16 & 14.58 \\
\hline & $64-66$ & 0.96 & 16.33 \\
\hline & $68-70$ & 1.22 & 16.00 \\
\hline & $72-74$ & 1.17 & 15.58 \\
\hline & $76-78$ & 1.24 & 16.00 \\
\hline & $80-82$ & 2.42 & 16.67 \\
\hline & $84-86$ & 1.30 & 16.00 \\
\hline
\end{tabular}

are stored at Imperial College, London and are available on request. Generally, the contents of most of the elements are very close to those of the average shale (Table 3 ). The small variation in most cases may be attributable to slight changes in admixture of mineral components. The lack of variation in the Al content with depth indicates little change in the overall content of aluminosilicates represented by clay min-
Table 3. Chemical Compositions of the Sediments from Cores MI and M4. Average Shale Data from Turekian and Wedepohl (1961) and Krauskopt in Brackets

\begin{tabular}{lccc}
\hline \multicolumn{1}{c}{ Element } & Range & Arithmetic Mean & Average Shale \\
\hline $\mathrm{Al}(\%)$ & $6.10-7.40$ & 6.72 & $8.00[9.2]$ \\
$\mathrm{Mg}(\%)$ & $1.82-2.10$ & 1.95 & $1.50[1.4]$ \\
$\mathrm{Na}(\%)$ & $1.96-2.70$ & 2.19 & $0.96[0.90]$ \\
$\mathrm{Ti}(\%)$ & $0.37-0.42$ & 0.39 & $0.46[0.45]$ \\
$\mathrm{Fe}(\%)$ & $4.00-4.30$ & 4.13 & $4.72[4.70]$ \\
$\mathrm{Ca}(\%)$ & $4.50-5.50$ & 5.01 & $2.21[2.50]$ \\
$\mathrm{K}(\%)$ & $1.85-2.10$ & 2.00 & $2.66[2.50]$ \\
$\mathrm{Mn}(\mathrm{ppm})$ & $1250-5500$ & 2500 & 850 \\
$\mathrm{Mi}(\mathrm{ppm})$ & $80-110$ & 91 & 68 \\
$\mathrm{Cr}(\mathrm{ppm})$ & $105-131$ & 115 & 90 \\
$\mathrm{Ba}(\mathrm{ppm})$ & $270-360$ & 305 & $580[600]$ \\
$\mathrm{V}(\mathrm{ppm})$ & $109-125$ & 119 & 130 \\
$\mathrm{Co}(\mathrm{ppm})$ & $22-27$ & 25 & 19 \\
$\mathrm{Sr}(\mathrm{ppm})$ & $171-220$ & 195 & 300 \\
$\mathrm{Li}(\mathrm{ppm})$ & $49-60$ & 56 & 66 \\
$\mathrm{~Pb}(\mathrm{ppm})$ & $28-59$ & 38 & 20 \\
$\mathrm{Rb}(\mathrm{ppm})$ & $80-115$ & 97 & 140 \\
$\mathrm{Bc}(\mathrm{ppm})$ & $1.9-2.2$ & 2.1 & 3 \\
$\mathrm{La}(\mathrm{ppm})$ & $25-28$ & 26 & $24[40]$ \\
$\mathrm{Ag}(\mathrm{ppm})$ & $1.0-1.29$ & - & $0.07[0.1]$ \\
$\mathrm{Cd}(\mathrm{ppm})$ & $0.57-0.92$ & - & 0.3 \\
$\mathrm{Zn}(\mathrm{ppm})$ & $79-136$ & 90 & 95 \\
$\mathrm{P}(\mathrm{ppm})$ & $520-700$ & 570 & $700[750]$ \\
$\mathrm{Cu}(\mathrm{ppm})$ & $37-55$ & 41 & $45[50]$ \\
$\mathrm{Mo}(\mathrm{ppm})$ & $1.0-2.4$ & - & $2.6[2]$ \\
\hline
\end{tabular}

erals, micas, feldspars, etc. The exception is the amounts of manganese and lead which noticeably are higher than usual for such basinal sediments, through-out the entire length of the cores. This suggests relatively high levels of supply for these two elements.

The elements, $\mathrm{Zn}, \mathrm{Pb}, \mathrm{P}, \mathrm{Cu}, \mathrm{Cr}$, and $\mathrm{Mn}$ show near-surface enrichment in the upper parts of the cores with values between 1.2 to 1.7 times greater than their background levels (Fig. 4). The surface enrichment in manganese is most likely due to upward diagenetic migration. It is clear that the increased content of manganese does not coincide with the increases of the other elements. A six element $(\mathrm{Cu}, \mathrm{Pb}, \mathrm{Zn}, \mathrm{Cr}, \mathrm{P}$, and $\mathrm{Mn}$ ) subset of data from M4 was subjected to Principal Components Analysis. This, together with a visual examination of bivariate plots, showed a clear separation between the process of primary scavenging of the metals by manganese and a variation in the concentration of the above trace elements which were unrelated to the distribution of manganese. Furthermore, an examination of the relationship of the above elements with organic carbon show that this does not seem to be the factor controlling their distribution. It therefore appears that there has been an increase in supply of these trace elements over the period represented by the upper part of the cores. The increase in content of such trace elements could be due to a 
natural change of source material because of uncovering of new rock types or changes in drainage patterns, or be due to diagenetic migration, but this seems unlikely. Whereas the magnitudes of these increases are considerably less than the scale of enrichment found in areas suffering strong anthropogenic pollution, nevertheless they appear likely to be of such an origin (see next section). However, on the basis of the data presented here, the site of sampling cannot be regarded as being polluted. Hence, these results give no support to the fears often expressed that the Sea of Marmara is becoming highly polluted, at least as far as the elements under discussion are concerned.

\section{The Age and Sources of the Sediments}

The ${ }^{210} \mathrm{~Pb}$ dating method was used to date the sediments in core $\mathrm{M} 1 .{ }^{210} \mathrm{~Pb}$ was determined through its daughter ${ }^{210} \mathrm{Po}$, in radioactive equilibrium with its parent. About one gram of dry sample was used in each determination. Details of the method were described in Erten and others, (1985). The ${ }^{210}$ Po samples were counted using a $\mathrm{Si}(\mathrm{Li})$ surface barrier detector (ORTEC $300 \mathrm{~mm}^{2}$ ). A least square analysis of the data indicates a sedimentation rate of $0.087 \pm 0.012 \mathrm{~g} /$ $\mathrm{cm}^{2} \cdot \mathrm{y}$. The activity of ${ }^{210} \mathrm{~Pb}$ was observed to be constant within a sediment depth of $5.5 \mathrm{~cm}$ (Fig. 5). Increased bioturbation is probably the most significant process producing this constant activity region in the top of core M1. The inventory of ${ }^{210} \mathrm{~Pb}$ in this sediment profile amounts to $80 \%$ of the expected atmospheric input if an atmospheric flux of ${ }^{210} \mathrm{~Pb}$ of 0.9 $\mathrm{dpm} \mathrm{cm}^{2} \cdot \mathrm{y}$ is assumed (Turekian and others 1983). As the organic carbon content varies between $1.0 \%$ $1.8 \%$ this means that the amount of organic carbon accumulating in the sediment on the floor of the Eastern Basin of the Sea of Marmara is between 8.7 to $15.7 \mathrm{~g} \cdot$ carbon $/ \mathrm{m}^{2} \cdot \mathrm{y}$.

If a similar sedimentation rate can be assumed throughout the cored interval, it suggests that this has accumulated in the last 1,000 years, i.e., after the full establishment of the present Black Sea-Marmara Sea stratified water system (Ross and Degens 1974). This correlation is supported by the presence of the coccoliths Emiliania huxleyi throughout the sequence. This coccolithophorid is a curyhaline species whose remains occur most commonly only in the surficial layer of the Black Sea deep-sea sediments (Bukry 1974), or Unit 1 of Ross and Degens (1974). The age of the unit is now believed to be between 1,000 (Degens and Stoffers 1980) to 2,000 years (Calvert and others 1987).

\section{M1}
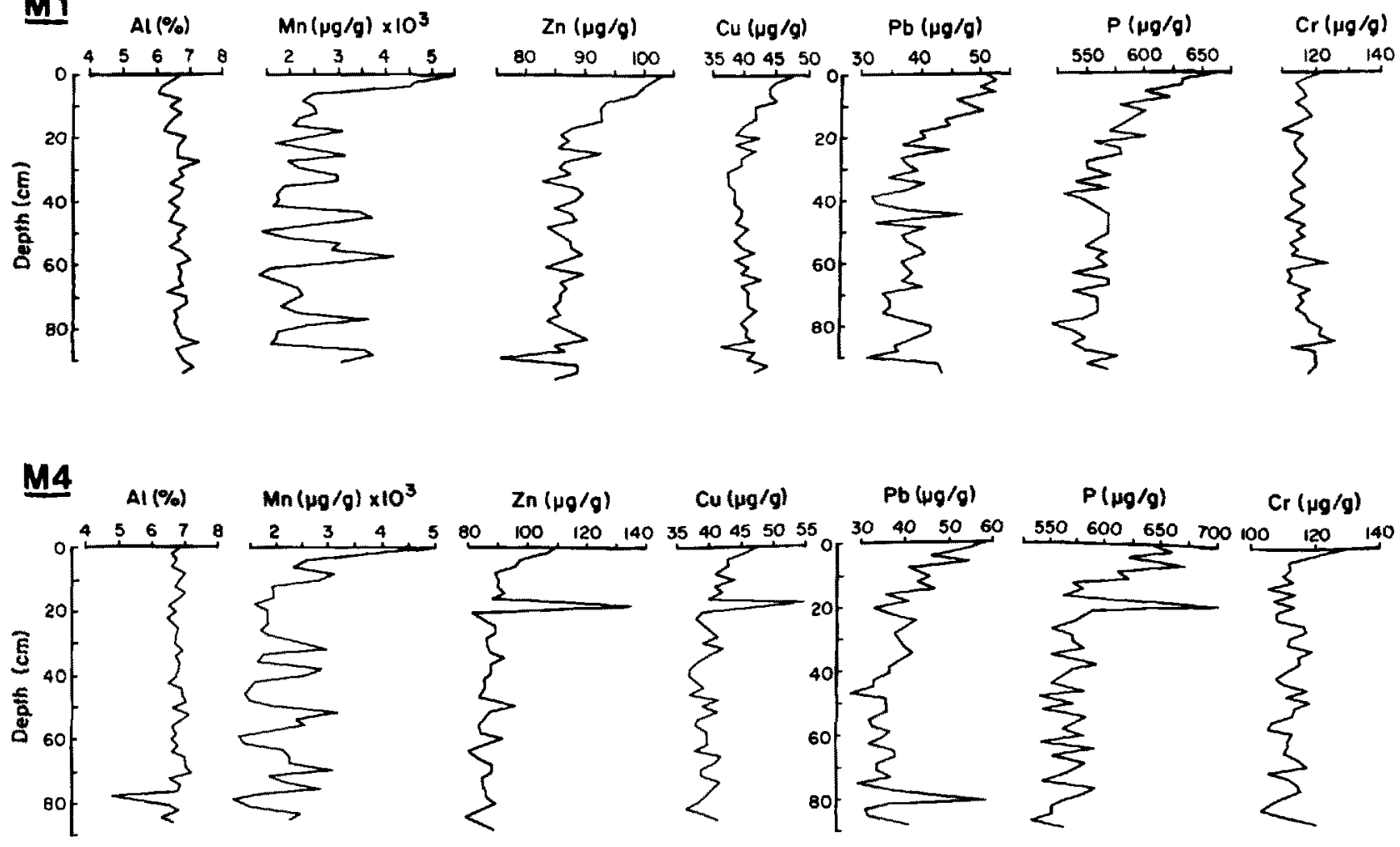

Figure 4. Vertical distributions of $\mathrm{Al}, \mathrm{Cu}, \mathrm{Mn}, \mathrm{Zn}, \mathrm{Pb}, \mathrm{Cr}$, and $\mathrm{P}$ in cores $\mathrm{Ml}$ and $\mathrm{M} 4$. 
In support of this, the microfaunal data discussed above are found to be comparable with some of those given by Stanley and Blanpied (1980) for the uppermost unit in their three cores G7, G8, and G9. There is also an increase in the abundance of foraminifers and the first appearance of the remains of pelecypods and echinoderms in this unit. It should also be noted that the same unit attains its maximum thickness of about $60 \mathrm{~cm}$ in core G7 of Stanley and Blanpied (1980) which is the nearest to the sites of the three cores discussed in this note. This possibly indicates a greater overall rate of sedimentation in the northwestern part of the basin.

Stanley and Blanpied (1980) correlated their upper unit with Unit 1 of Ross and Degens (1974), as it was found to be younger than about 4,500 years on the basis of the ${ }^{14} \mathrm{C}$ dating. Allowing for the dominantly silty composition of the sediments and the residence time of organic carbon in the sea-water (Calvert and others 1978), the radiocarbon dates can be up to about 2,000 years too old. This would mean that the bottom of the uppermost unit from the Eastern basin of Marmara is probably at most $2,000-2,500$ years old. Unfortunately, due to the very small contents of sand grade carbonate, it is impossible to obtain a radiocarbon date over a sufficiently short interval to be meaningful.

The ${ }^{210} \mathrm{~Pb}$ age determinations suggest that the increased contents of $\mathrm{Pb}, \mathrm{Zn}, \mathrm{Cu}$, and $\mathrm{P}$ have accumulated over approximately the last 200 years, i.e. since approximately the latter part of the eighteenth century, with a more recent increase in $\mathrm{Cr}$ content.

Interestingly, the end of the eighteenth century during the reign of Selim III was the period when great changes were being introduced in the Ottoman army

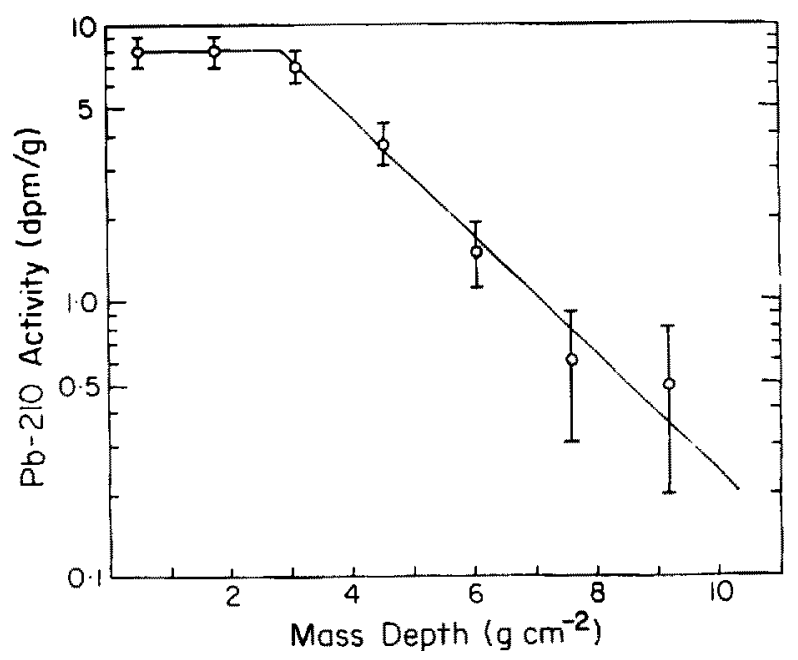

Figure 5. Activitics of "unsupported" ${ }^{210} \mathrm{~Pb}$ versus depth of sediment core M1. The solid line is the least squares fit to the data. and navy. New foundaries, armament works, and shipyards were being constructed in and around Istanbul. Also, copper plating was being introduced on the bottom of ships (Shaw 1971). There is, therefore, the possibility that the increased contents of various metals which appear to characterize the upper part of the cores could have an anthropogenic source, and were initiated by the beginning of this activity. This appears to be the most reasonable explanation for the increased metal contents as it seems unlikely that they were produced by changes in the natural supply or are due to diagenetic changes.

At present, little evidence is available on the source of the sediments. Whereas the biogenic portion and the included organic matter may be largely produced locally, some of the latter may have come from the Black Sea and the Bosporus. The siliciclastic sediments, which are essentially silt and clay, are likely to be mainly derived from the adjacent coastlines of Anatolia and to a lesser extent Thrace, as it appears that the rivers draining the southern coastal areas of the Sea of Marmara act as the main agents of terrigenous sediment supply to this land-locked and silled basin.

\section{Conclusions}

The superficial sediments of the Eastern Basin of the Sea of Marmara (that is the top $90 \mathrm{~cm}$ ), as represented by the three cores, show the following interesting features:

1. They have accumulated mainly through hemipelagic sedimentation with only a limited amount of gravity-flow or bottom-current action. This is indicated by sedimentary structures, grain-size composition, and benthic foraminiferal evidence.

2. Their high organic carbon contents clearly reflect both the stratified nature of the overlying water column and its enhanced productivity leading to a low content of oxygen in the bottom waters. These conditions are also reflected in the microfaunal contents of the sediments.

3. The presence of hyaline calcareous benthic foraminifers and calcareous benthic macrofauna together with abundant bioturbation throughout the sequence clearly shows that the environment has never become anoxic during the accumulation of the cored interval.

4. The sediment has a similar composition to normal shale except for an anomalously high content of manganese and to a lesser extent of lead.

5. The upper parts are enriched in $\mathrm{Zn}, \mathrm{Pb}, \mathrm{Cu}, \mathrm{P}$, $\mathrm{Cr}$, and $\mathrm{Mn}$. It seems likely that the increased proportion of these elements, except for manganese, may be partly or entirely from anthropogenic sources. 
However, it should be stressed, the area cannot in any way be regarded as polluted, as far as these elements are concerned.

6. Except for the slight change in some of the faunal elements-indicating somewhat more restricted conditions upward - and the slight changes in some elements; conditions appear to have remained uniform over the time interval represented by the sediments above the supposed erosional surface at the base of the cores. This interval, if the ${ }^{210} \mathrm{~Pb}$ results are projected throughout the length of the cores is approximately one thousand years.

7. The ${ }^{210} \mathrm{~Pb}$ determinations indicate that the increased $\mathrm{Pb}, \mathrm{Zn}, \mathrm{Cu}$, and $\mathrm{P}$ contents have accumulated since the latter part of the eighteenth century, with more recent increases in $\mathrm{Cr}$.

8. The organic carbon and the calcium carbonate contents of the sediments are appreciably different from those reported by Stanley and Blanpied (1980) from adjacent sites. These differences are presumably due to different techniques of analysis; however, the authors did not describe the techniques they employed.

9. Unfortunately, due to their short lengths and their location in deep waters, the cores did not show the interesting changes described by Stanley and Blanpied (1980). However, the interval described in this paper may correspond to the upper unit of these authors in their cores $\mathrm{G} 7, \mathrm{G8}$, and G9; and may be correlated with the coccolith-rich surficial deep-sea sedimentary unit of Ross and Degens (1974) in the Black Sea.

\section{Acknowledgments}

We wish to acknowledge our gratitude to Professor $U$. Unluata for arranging the collection of the cores onboard the $R / V$ Bilim of the Middle East Technical University and his comments on an earlicr version of this manuscript; also to the Natural Environment Research Council of Great Britain for the use of two boomerang corers. We also thank J. Young, P. Grant, M. Thompson, S. Phethean, M. H. Ramsey, E. Rossler, U. Krahenbuhl, M. Ursinus, and $M$. Gill for help with the analyses and production of this note and H. Shaw and I. Salihoglu for their comments.

\section{References}

Alavi SN (1988) Late Holocene deep-sea benthic Foraminifera from the sea of Marmara. Marine Micropalacontology, (in press)

Anastasakis G (1985) Red-Eastern Mediterranean-Marmara-Black Sea stagnation laycrs: sequence development and time succession. Rapports Commission Internationale Mer Mediterranée 29:229-230

Anastasakis GC, Stanley DJ (1984) Sapropel and organic-rich variants in the Mediterranean: sequence, development and classification. In: Stow DAV. Piper DJW (cds) Fine-Grained Sediments, Deep-Water Processes and Facies. Blackwell Scientific Publications, London, pp 104-510
Basturk O, Saydam AC, Salihoglu I, Yilmaz A (1986) Oceanography of the Turkish Straits: chemical and environmental aspects of the Sea of Marmara. Erdemli, Icel, $86 \mathrm{pp}$

Be'AWH (1977) An ecological, zoogcographic and taxonomic review of Recent planktic Foraminifera. In: Ramsay ATS (ed) Oceanic Micropalacontology I Academic Press, London, pp 1100

Blanc-Vernet L. Sgarrella F, Acquaviva M (1984) Evenements climatiques, hydrologie et Foraminiferes en Mediterranée au Quaternaire récent. Bulletin Societe geologic France 7 (26-6): $1235-1243$

Brunner CA. Normark WR (1985) Biostratigraphic implications for turbidite despositional processes on the Monterey deep-sea fan, Central California. Journal Sedimentary Petrology 55:495505

Bukry D (1974) Coccoliths as paleosalinity indicators: cvidence from the Black Sea. American Association Petroleum Geologist Memoir 20:353-363

Calvert SE. Vogl JS, Southon JR (1987) Carbon accumulation rates and the origin of the Holocene sapropel in the Black Sea. Geology 15:918-921

Carson B, Baker ET. Hickey BN. Niturouer CA, DeMaster DJ, Thorbjarnrson KW, Synder GW (1986) Modern sediment dispersal and accumulation in Quinault submarine canyon-A summary. Marine Geology 71:1-13

Corliss BH (1985) Microhabitats of benthic Foraminifera within deep-sea sediments. Nature 314:435-438

Degens ET. Stoffers P (1980) Environmental events recorded in Quaternary sediments of the Black Sca. Journal Geological Society, London 137:131-138

D.S.I. (State Hydrologic Services) (1985) Su kalitesi gozlem yilligi 1979-1982 (Observations on water quality during the years 1979-1982). General Directorate of the D.S.I. Ankara. 527 pp (in Turkish)

D.S.I. (State Hydrologic Services) (1987) Su kalitesi gozlem yilligi 1983-1984 (Observations on water quality during the years 1983-1984). Gencral Dircctorate of the D.S.I. Ankara. $511 \mathrm{pp}$ (in Turkish)

Erten HN, Von Gunten HR, Rossler E, Sturm M (1985) Duting

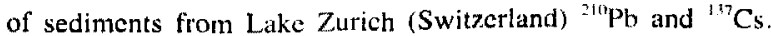
Schweizerische Zcitschift Hydrologie 47:5-11

Koreneva EV (1971) Spores and pollen in Mediteranean bottom scdiments. In: Funnel BM. Rjedel WR (eds) The Micropalaeontology of Occans. Cambridge University Press, London, pp 361371

Krauskopf KB (1982) Introduction to Geochemistry. McGraw-Hill, Singapore, $617 \mathrm{pp}$

Miller AR (1983) The Mediterranean Sca: Physical Aspects. In: Ketchum BH (ed) Estuaries and Enclosed Seas. Ecosystems of the World v26. Elsevier, Amsterdam. pp 219-238

Mullincaux LS, Lohmann GP (1981) Late Quaternary stagnation and recirculation of the eastern Meditetranean; changes in decpwater recorded by fossil benthic Foraminifera. Journal Foraminiteral Research 11:20-39

Nolet G, Corliss BH (1987) Benthic foraminiferal response to sap ropel deposition in the late Quaternary: Eastern Mediterranean EOS $68(16): 329$

Ozsoy E, Oguz T. Latif MA, Unluata U (1986) Occanography of the Turkish Struits: physical oceanography of the Turkish Straits. Erdemli, Icel 1.34 pp

Ross DA, Degens ET (1984) Recent sediments of the Black Sea. American Association Petrolcum Geologists Menoir 20:183199

Shaw SJ (1971) Between Old and New. Harvard University Press. Cambridge Massachusetts, $535 \mathrm{pp}$ 
Shimkus KM, Trimonis ES (1974) Modern sedimentation in the Black Sea. American Association Petroleum Geologist Memoir 20:249-278

Stanley DJ, Blanpied C (1980) Late Quaternary water exchange between the eastern Mediterrancan and the Black Sea. Nature $285: 537-541$

Thunell RC (1978) Distribution of Recent planktonic Foraminifera in surface sediments of the Mediterrancan Sea. Marine Micro. palaeontology 3:147-173

Turekian KK. Beninger LK, Dion EP (1983) ${ }^{7}$ Be and ${ }^{211} \mathrm{~Pb}$ total deposition fluxes at New Haven Connecticut and Bermuda. Journal Geophysical Research 88 C9:5411-5415

Turekian KK, Wedepohl KH (1961) Distribution of elements in some major units of the Earth's crust. Geological Socicty American Bulletin 72:175-192

Unluata U, Ozsoy E (1986) Oceanography of the Turkish Straits: oxygen deficiency of the Sea of Marmara. Erdemli, Icel, $77 \mathrm{pp}$

Manuscript received 9 June 1988; revision received 15 September 1988. 